\title{
Pendidikan Lingkungan "Microplastic and Marine Pollution Awareness" di Sekolah Adiwiyata Nasional: SMAN 1 Cikarang Pusat, Cikarang, Jawa Barat
}

\author{
Filson M. Sidjabat \\ Program Studi Teknik Lingkungan, Fakultas Teknik, Universitas Presiden, \\ fmsidjabat@president.ac.id
}

\begin{abstract}
ABSTRAK
Permasalahan lingkungan besar yang dihadapi dunia, khususnya di Indonesia adalah isu pencemaran plastik, mikroplastik, dan pencemaran laut. Permasalahan mikroplastik dan pencemaran lautan menjadi pekerjaan rumah yang besar bagi berbagai pihak termasuk dunia pendidikan sebagai agen perubahan. Peserta kegiatan Pengabdian kepada Masyarakat (PKM) ini adalah para Duta Lingkungan yang terlibat dalam kegiatan ekstrakurikuler di SMA Negeri 1 Cikarang Pusat, peraih Sekolah Adiwiyata Tingkat Nasional. Metode yang digunakan adalah pendidikan lingkungan memberikan wawasan terkait (a) mikroplastik dan pencemaran lautan, (b) solusi pengolahan dan pengelolaan yang bisa dilakukan dalam skala rumah tangga, dan (c) perubahan perilaku peserta untuk peduli terhadap permasalahan lingkungan. Kegiatan PKM ini terdiri dari 2 jenis yaitu Pendidikan Lingkungan (presentasi dan diskusi) dan Lomba Poster Kreatif. Pendidikan lingkungan dibutuhkan sejak usia remaja supaya kesadaran akan masalah ini dapat tertanam sejak usia muda. Kegiatan ekstrakurikuler dalam rangka Adiwiyata, seperti Duta Lingkungan, merupakan kegiatan yang dapat menjadi pusat pembelajaran mengenai lingkungan hidup yang baik di sekolah, juga menimbulkan banyak perubahan positif bagi perilaku bermasyarakat. Selanjutnya peserta dilibatkan dalam Lomba Poster kreatif dengan tema peduli lingkungan.
\end{abstract}

Kata-kata Kunci: Mikroplastik, Pencemaran Lautan, Duta Lingkungan, Pendidikan Lingkungan, Adiwiyata.

\begin{abstract}
Nowadays, the world, especially Indonesia are facing the three biggest environmental problems, which are plastic pollution issue, microplastic, and marine pollution. Microplastic and marine pollution problems are becoming a major homework for many stakeholders, including education sector, as an agent of change. The participants of this community empowerment project are Environmental Agents, who actively engage in extracurricular activities in SMA Negeri 1 Cikarang Pusat, an Adiwiyata Green Schools national award winner. The method that been used is environmental education, that giving knowledge about (a) microplastic and marine pollution, (b) how to treat and manage the solution in household scale, and (c) how the participants became active in changing their behaviors, and increasing careness in this problems. The activities are divided into 2 type: Environmental Education (Presentation and Sharing) and Creative Poster Competition. This event are needed for young leaders to increase their awareness and plant wisdom in since they are young. The extracurriculer activities in Adiwiyata Green Schools, like Environmental Agent are becoming a great education center for environmental issue in schools, and also can contribute to positive changing of society behaviors.
\end{abstract}

Keywords: Microplastic, Marine Pollution, Environmental Agent, Environmental Education, Adiwiyata.

\section{PENDAHULUAN}

Permasalahan lingkungan besar yang dihadapi dunia, khususnya di Indonesia adalah isu pencemaran plastik (plastic pollution), mikroplastik (microplastic), dan pencemaran laut (marine pollution/debris). Indonesia menjadi penyumbang sampah plastik terbesar ke lautan kedua setelah Tiongkok (Jambeck, Geyer, Wilcox, Siegler, Perryman, Andrady, Narayan, 
dan Law, 2015). Pengelolaan sampah yang buruk berimbas pada banyaknya sampah yang masuk ke badan air dan bermuara ke lautan. Prediksi menunjukkan total jumlah sampah Indonesia di 2019 akan mencapai 68 juta ton, dan sampah plastik diperkirakan akan mencapai 9,52 juta ton atau $14 \%$ dari total sampah yang ada. Penelitian terbaru juga menemukan plastik dalam makanan laut, margasatwa, air keran, dan sekarang dalam garam. Lebih dari $90 \%$ merek garam yang disampel secara global ditemukan mengandung mikroplastik, dimana jumlah tertinggi bersumber dari sampel garam di Asia (Kim, Jisu, 2018). Hal ini juga mendatangkan respon dari pemerintah yang segera mengeluarkan Perpres RI No. 15 Tahun 2018 tentang Percepatan Pengendalian Pencemaran dan Kerusakan DAS Citarum, dan Perpres RI No. 83 Tahun 2018 tentang Penanganan Sampah Laut. Isu ini menjadi pekerjaan rumah yang besar bagi berbagai pihak termasuk dunia pendidikan sebagai agen perubahan.

Pencemaran plastik di lautan semakin buruk dan mengancam keberlangsungan hidup manusia dan biota laut (Ambari, 2018). Dalam dua penelitian terbaru di Indonesia, sampel garam dan ikan pun sudah terkontaminasi oleh mikroplastik. Peneliti dari Universitas Hasanuddin Makassar dan Pusat Oceanografi Lembaga IImu Pengetahuan Indonesia menemukan fakta ini dalam penelitian mereka yang berbeda. Menurut Reza Cordova, peneliti kimia laut dan ekotoksikologi Pusat Penelitian Oseanografi LIPI, telah ditemukan 1020 partikel plastik mikro per kilogram garam. Jenis plastik pada garam mirip dengan temuan di air, sedimen, dan biota di sekitarnya. Hewan laut yang berada di perairan dalam pun tak bisa menghindari ancaman sampah plastik. Pasalnya, kantung plastik belanjaan berhasil ditemukan di kedalaman 10.994 meter di Palung Mariana, tempat terdalam yang saat ini mampu diobservasi di Bumi. Fakta ini membuktikan betapa daruratnya masalah sampah plastik di dunia (Siaran Pers Greenpeace Indonesia, 2018, dan Browne, Crump, Niven, Teuten, Tonkin, Galloway, \& Thompson, 2011).

Penemuan lainnya dipublikasikan pada Jurnal Environmental Science \& Technology, yang menegaskan bahaya plastik terhadap beragam bentuk kehidupan mulai dari moluska hingga manusia. Pada Tahun 2016, 335 juta metrik ton plastik telah diproduksi, 40\% berupa plastik sekali pakai. Plastik akan terurai menjadi mikroplastik saat terpapar sinar ultraviolet. Para ilmuwan memperkirakan, sekitar 51 triliun mikroplastik tersebar di lautan--dan jumlahnya kemungkinan akan meningkat. Mikroplastik ini akan berubah lagi menjadi nano partikel yang dapat dengan mudah masuk ke tubuh hewan, lalu manusia, melalui rantai makanan. Tim Peneliti Austria juga telah menemukan bukti bahwa mikroplastik-potongan, fragmen, dan serat plastik-ternyata terakumulasi pada kotoran manusia. Artinya, manusia telah terpapar mikroplastik dari hewan laut yang dikonsumsinya (Browne, et al., 2011). 
Permasalahan mikroplastik dan pencemaran lautan ini menjadi pekerjaan rumah yang besar bagi berbagai pihak termasuk dunia pendidikan sebagai agen perubahan. Sebagai tanggapan perguruan tinggi dalam permasalahan ini, diperlukan keterlibatan lembaga pendidikan tinggi dalam mengamalkan tridharma-nya, diantaranya berupa pendidikan lingkungan. Pemahaman terhadap permasalahan ini dan kesadaran lingkungan dalam sikap dan tingkah laku terhadap konsumsi sampah perlu ditingkatkan. Dalam pendidikan, perlu juga dilakukan inovasi pembelajaran: kerja kelompok, observasi, kajian pustaka, juga kuliah kerja nyata tematik, seperti: pendidikan karakter melalui pengalaman nyata di lapangan dan kerja bersama masyarakat mengatasi masalah lingkungan. Atas dasar tersebut perlu ditingkatkan pendidikan lingkungan terkait permasalahan mikroplastik dan pencemaran laut di Indonesia, di berbagai golongan masyarakat. Kegiatan ini juga sesuai dengan Roadmap Penelitian dan Pengabdian Masyarakat Universitas Presiden dalam tema: Green Technology and Sustainability, dalam topik: Green Campaign, Green Environment Awareness, dan Pengelolaan Lingkungan.

Tujuan PKM ini adalah:

1. Melakukan pendidikan lingkungan untuk memberikan wawasan dan meningkatkan kesadaran serta kepedulian terhadap permasalahan nukroplastik dan pencemaran lautan di Indonesia

2. Mengangkat permasalahan mikroplastik dan pencemaran laut sebagai isu permasalahan lingkungan yang penting di Provinsi Jawa Barat, khususnya di berbagai lembaga pendidikan dan kelompok masyarakat di daerah sekitar Cikarang

3. Membuat berbagai kreasi, termasuk panduan ataupun materi penyuluhan yang dapat dimultiplikasi oleh berbagai golongan masyarakat.

\section{METODE PELAKSANAAN}

\subsection{Penentuan Lokasi}

SMA Negeri 1 Cikarang Pusat menjadi lokasi kegiatan PKM ini. Sekolah ini memegang gelar Sekolah Adiwiyata Tingkat Nasional yang telah didukung dengan adanya kegiatan ekstrakurikuler Duta Lingkungan (lihat Gambar 1). Peserta PKM ini tidak hanya dari SMA Negeri 1 Cikarang Pusat saja, namun juga dua sekolah yang merupakan sekolah binaan SMA Negeri 1 Cikarang Pusat dalam pelestarian lingkungan hidup, yakni SMA Negeri 2 Cikarang Utara dan SMP Negeri 4 Cikarang Utara. 


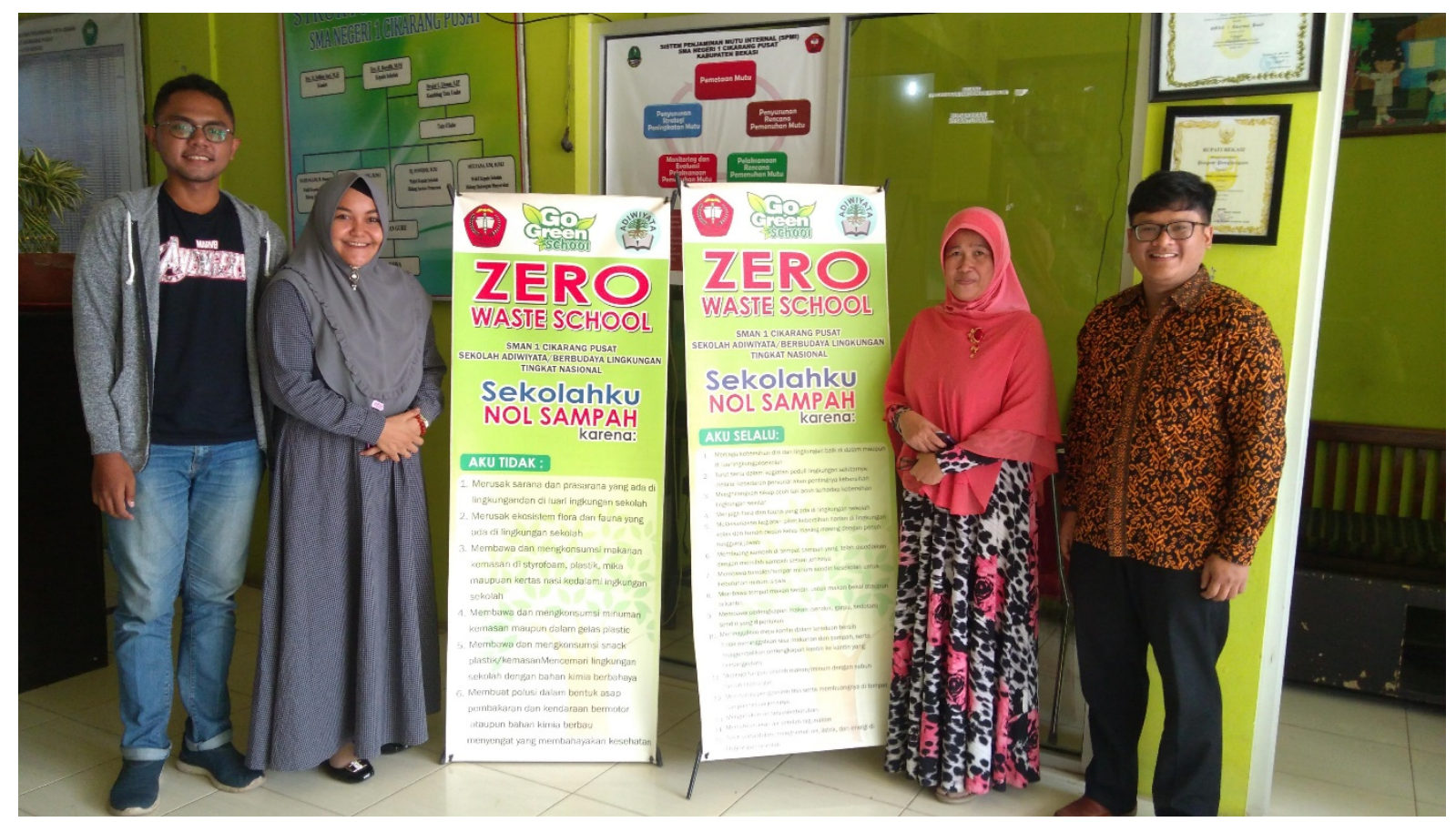

Gambar 1.

Pembina Adiwiyata SMAN 1 Cikarang Pusat

Metode yang digunakan dalam kegiatan pengabdian masyarakat ini adalah pendidikan lingkungan memberikan wawasan terkait (1) mikroplastik dan pencemaran lautan, (2) pengolahan dan pengelolaan yang bisa dilakukan dalam skala rumah tangga, dan (3) perubahan perilaku dan peduli terhadap permasalahan lingkungan.

Kegiatan pengabdian masyarakat ini terdiri dari 2 kegiatan yaitu:

1. Pendidikan Lingkungan - Mikroplastik dan Pencemaran Lautan

Kegiatan ini bertujuan untuk meningkatkan wawasan dan kesadaran lingkungan terkait permasalahan mikroplastik dan pencemaran lautan. Peserta diajak untuk berdiskusi, mengisi kuesioner, dan melihat beragam informasi dan multimedia yang disiapkan oleh tim.

2. Lomba Poster Kreatif

Setelah pendidikan lingkungan, peserta diajak untuk membentuk kelompok-kelompok kecil untuk membuat poster kreatif dan penilaian dilakukan oleh dosen dan guru wali dari kedua sekolah. Poster ini mendorong peserta menyampaikan pesan sederhana dan persuasif untuk meningkatkan wawasan dan kesadaran orang yang melihat poster tersebut.

\section{HASIL DAN PEMBAHASAN}

\subsection{Pengetahuan Peserta sebelum Pendidikan Lingkungan}


Sebelum pendidikan lingkungan diberikan, peserta diminta untuk mengisi kuesioner untuk mengetahui sejauh mana pengetahuan peserta tentang mikroplastik dan pecemaran lautan. Kuesioner dibagikan dalam bentuk google form yang diisi oleh responden, yaitu peserta kegiatan PKM. Berikut ini hasil dan pembahasan dari pertanyaan yang ada dalam kuesioner. Pada Gambar 2, dari 68 peserta kegiatan PKM, 62\% dari total peserta berusia 14-15 tahun. Kegiatan PKM ini dihadiri oleh siswa/i SMP dan SMA yang duduk di bangku kelas 9-11.

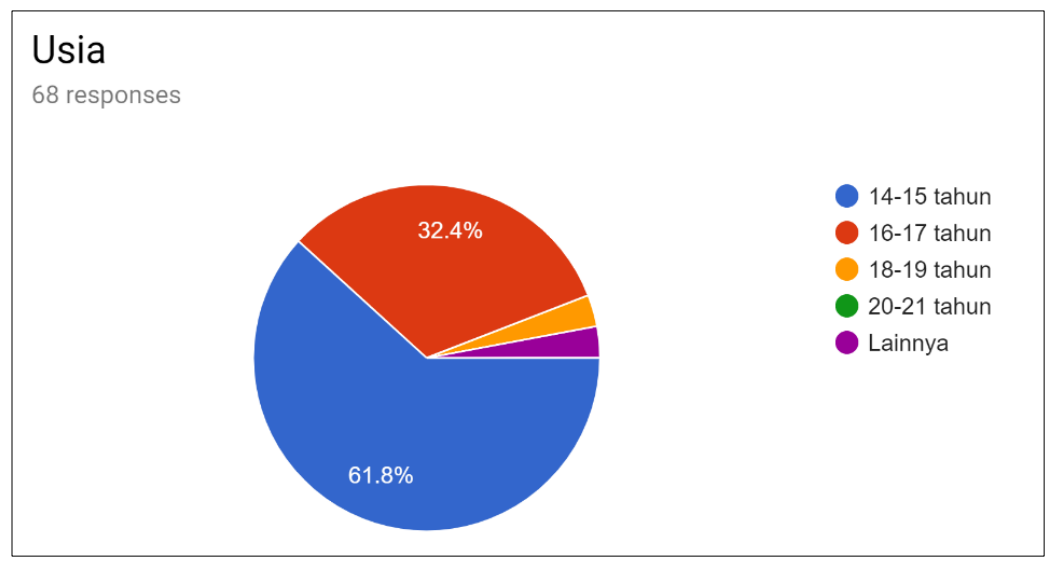

Gambar 2.

Usia Peserta

Pada Gambar 3, pengetahuan tentang mikroplastik dan pencemaran sudah dimiliki oleh mayoritas peserta, namun tidak demikian untuk pengetahuan tentang jenis-jenis mikroplastik, yaitu mikroplastik primer dan sekunder. Hal ini telah menjadi bagian dari materi PKM ini. Peserta PKM juga sebagian besar adalah anggota kegiatan ekstrakurikuler Duta Lingkungan Hidup SMAN 1 Cikarang Pusat dan sebagian lainnya adalah siswa dan siswi SMA dan SMP yang peduli dengan lingkungan.

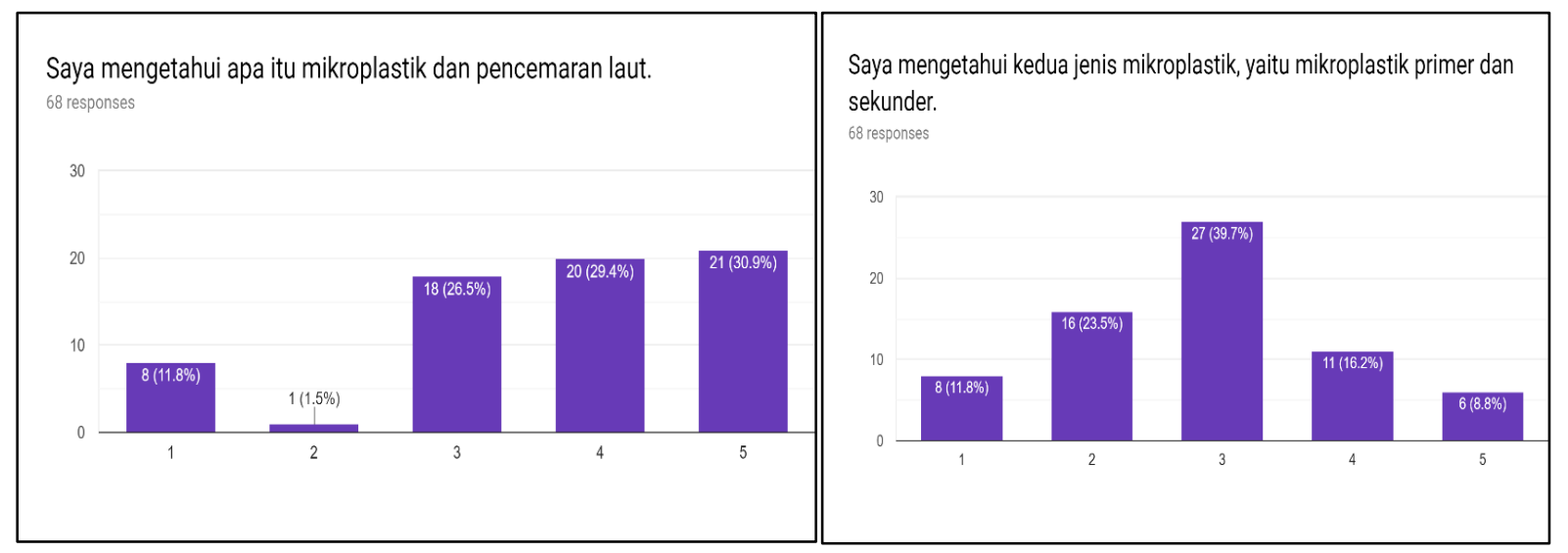

Gambar 3.

Pengetahuan tentang Mikroplastik dan Pencemaran Laut 
Pada Gambar 4, mayoritas dari anggota peserta PKM memilih untuk menjadi anggota organisasi lingkungan atau menjadi siswa yang peduli lingkungan adalah karena keinginan mereka sendiri. Hal ini menunjukan bahwa responden sudah memiliki kesadaran yang cukup tinggi dan keterlibatan aktif terhadap permasalahan yang terjadi di lingkungan hidup.

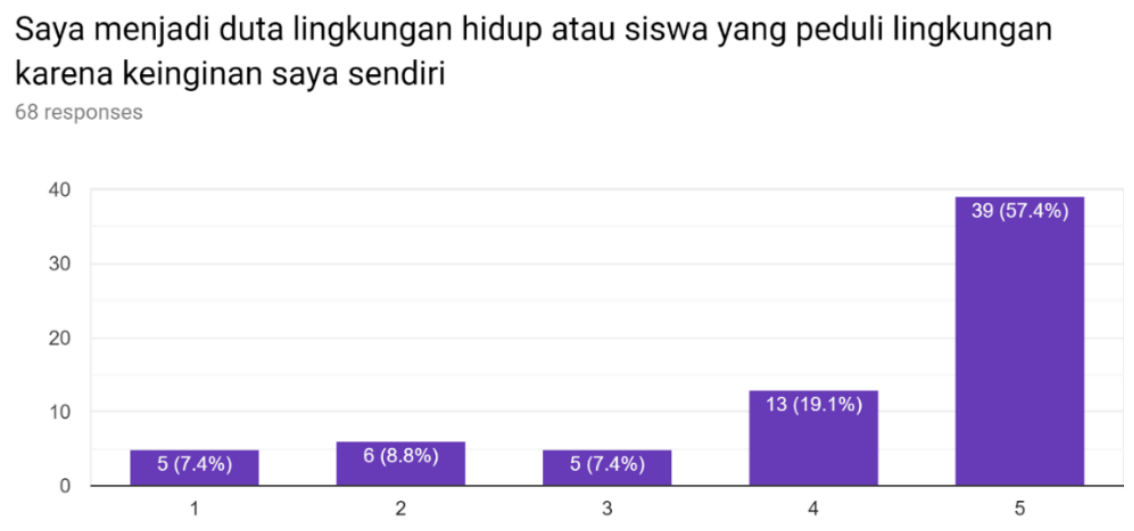

Gambar 4.

Kesadaran untuk Mengurangi Sampah Plastik

Pada Gambar 5, sekitar 34 persen dari peserta PKM belum konsisten untuk mengurangi penggunaan plastik sekali pakai. Hal ini bisa terjadi karena berbagai faktor, seperti kurangnya fasilitas atau peralatan yang mendukung untuk mengurangi plastik sekali pakai. Faktor lain adalah kebiasaan yang belum terbentuk dengan nilai yang kuat, walaupun orang lain tidak melakukan hal yang sama.

Saya telah menolak barang atau sampah sekali pakai seperti styrofoam, tissue, piring plastik, pembersih kuping, sedotan plastik, dan lain lain 68 responses

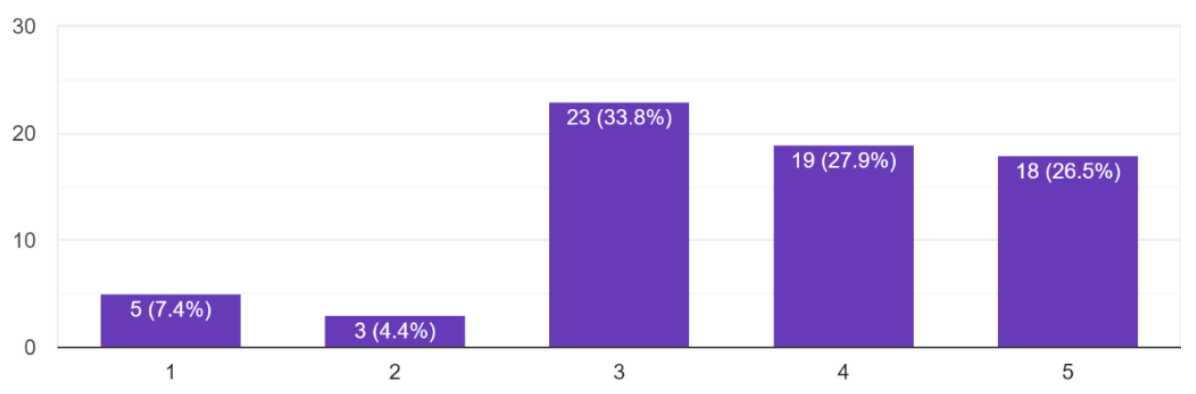

Gambar 5.

Upaya Mengurangi Sampah Sekali Pakai

\subsection{Kegiatan Pendidikan Lingkungan Mikroplastik dan Pencemaran Lautan}

Mikroplastik merupakan partikel plastik yang diameternya berukuran kurang dari $5 \mathrm{~mm}$. Batas bawah ukuran partikel yang termasuk dalam kelompok mikroplastik belum didefinisikan secara pasti namun kebanyakan penelitian mengambil objek partikel dengan 
ukuran minimal $300 \mu \mathrm{m} 3$. Mikroplastik terbagi lagi menjadi kategori ukuran, yaitu besar (1-5 $\mathrm{mm}$ ) dan kecil (<1 mm). Sumber mikroplastik terbagi menjadi dua, yaitu primer dan sekunder. Mikroplastik primer merupakan butiran plastik murni yang mencapai wilayah laut akibat kelalaian dalam penanganan. Sementara itu, mikroplastik sekunder merupakan mikroplastik yang dihasilkan akibat fragmentasi plastik yang lebih besar. Sumber primer mencakup kandungan plastik dalam produk-produk pembersih dan kecantikan, pelet untuk pakan hewan, bubuk resin, dan umpan produksi plastik. Pada umumnya, mikroplastik yang masuk ke wilayah perairan berasal dari saluran limbah rumah tangga, dan di dalamnya terdapat polietilen, polipropilen, dan polistiren. Sumber sekunder dari mikroplastik dapat berbentuk serat atau fragmen kecil dari plastik yang lebih besar. Fragmen kecil ini dapat berasal dari bahan baku industri, kantong paslik yang degradable, serat sintesis, jala ikan dan peralatan pancing lainnya, peralatan/perkakas rumah tangga, atau juga akibat pelapukan beragam barang berbahan dasar plastik. (Browne, Crump, Niven, Teuten, Tonkin, Galloway, \& Thompson, 2011).

Sejumlah faktor telah diperkirakan sebagai penyebab banyaknya mikroplastik yang ada di lingkungan perairan tawar. Beberapa di antaranya adalah perbandingan populasi manusia dibandingkan dengan jumlah sumber air, letak pusat perkotaan, waktu tinggal air, ukuran sumber air, jenis pengolahan limbah, dan jumlah saluran pembuangan. Para peneliti mengatakan bahwa jumlah partikel pelagis tinggi ditemukan dalam danau-danau dengan populasi manusia yang rendah akibat waktu tinggal air yang tinggi dan ukuran danau yang besar. Mereka juga mengatakan bahwa pola tersebut juga menjelaskan alasan danau-danau yang lebih besar mengandung lebih sedikit mikroplastik bila dibandingkan dengan danau yang ukurannya lebih kecil namun densitas partikelnya lebih tinggi (Alencastro, D, 2012).

Masalah utama dari mikroplastik, berkembang juga dari buruknya pengelolaan sampah di daratan, sehingga banyak sampah yang akhirnya bermuara ke lautan. Kementerian Lingkungan Hidup dan Kehutanan (KLHK) menilai persoalan sampah sudah meresahkan. Indonesia bahkan masuk dalam peringkat ke-2 di dunia sebagai penghasil sampah plastik ke laut setelah Tiongkok, Cina. Hal ini berkaitan dengan data dari KLHK yang menyebut plastik hasil dari 100 toko atau anggota Asosiasi Pengusaha Ritel Indonesia (APRINDO) dalam waktu 1 tahun saja, sudah mencapai 10,95 juta lembar sampah kantong plastik. Jumlah itu ternyata setara dengan luasan 65,7 hektare kantong plastik atau sekitar 60 kali luas lapangan sepak bola. Dirjen Pengelolaan Sampah, Limbah dan B3 KLHK Tuti Hendrawati Mintarsih menyebut total jumlah sampah Indonesia di 2019 akan mencapai 68 juta ton, dan sampah plastik di perkirakan akan mencapai 9,52 juta ton atau $14 \%$ dari total sampah yang ada. (Tri Wahyuni, 2016) 


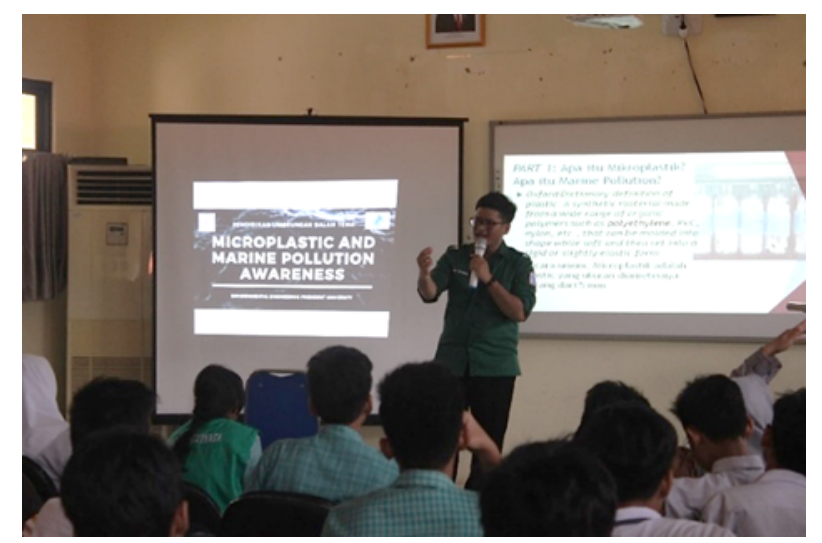

Gambar 6.

Penyampaian Materi Mikroplastik dan Marine Pollution

Dalam kegiatan pendidikan lingkungan ini (Gambar 6), siswa diajak untuk memahami permasalahan mikroplastik dan pencemaran lautan saat ini. Siswa diajak untuk mengerti sumber-sumber mikroplastik, dan bagaimana bijak dalam menggunakan produk-produk plastik, juga produk yang didalamnya terdapat mikroplastik (microbeads, microfilms, microfibers) (lihat Gambar 6). Kesadaran akan dampak penggunaan plastik yang bermuara ke lautan, juga disampaikan agar peserta dapat lebih bijak dalam menggunakan barang berbahan plastik, dan dalam mengelola sampah plastik Beragam barang berbahan plastik bisa menjadi fragmen-fragmen kecil (makro ataupun mikro) di beragam proses fisik di lautan. Dampak dari mikroplastik ini dapat merusak ekosistem yang ada dan masuk ke rantai makanan biota laut dan juga manusia.

\subsection{Kegiatan Lomba Poster Kreatif}

Di kegiatan kedua, para peserta secara berkelompok diminta untuk membuat poster yang bertemakan pengetahuan mikroplastik dan pencemaran lautan (lihat Gambar 7).

Peserta PKM ini adalah generasi muda para agen perubahan untuk lingkungan yang lebih baik. Kegiatan sekolah dalam rangka Adiwiyata, sangatlah bermanfaat dalam mendidik siswa dan guru agar terlibat aktif mencari solusi dari beragam permasalahan lingkungan yang di sedang dihadapi. Karakter jujur, cerdas, peduli, dan berbudi pekerti yang baik dapat dikembangkan dengan kegiatan sekolah di bagian lingkungan hidup ini. Semangat dan kreatifitas generasi muda ini juga membawa harapan akan perubahan lingkungan yang semakin baik.

Dibutuhkan agen perubahan yang terus bergerak menginisiasi dan menciptakan komunitaskomunitas peduli lingkungan yang memiliki program kerja dan kegiatan yang berkelanjutan. Mahasiswa Universitas Presiden juga memiliki peran yang penting dalam kegiatan pengabdian kepada masyarakat ini. Wawasan, semangat, dan teladan yang baik dapat mereka berikan dan inilah yang menjadikan Universitas Presiden memiliki nama yang baik karena telah bermanfaat bagi lingkungan sekitarnya (Sidjabat, Ismail \& Rismauli, 2020, dan Ismail \& Sidjabat, 2019). 


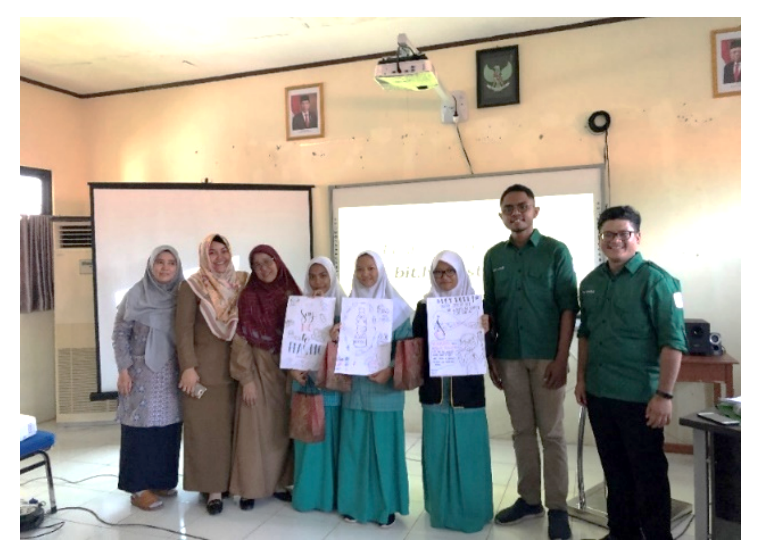

Gambar 7.

Pemenang Lomba Poster Mikroplastik dan Marine Pollution

\section{KESIMPULAN}

Kegiatan PKM dalam bentuk Pendidikan Lingkungan kepada siswa siswi SMP dan SMA ataupun remaja perlu terus dilanjutkan, untuk mengatasi masalah mikroplastik dan pencemaran lautan. Hal mendasar yang perlu ditingkatkan adalah kesadaran beragam masalah lingkungan yang terjadi akibat isu ini dan bagaimana cara pencegahan serta penanggulangannya. Pendidikan lingkungan ini dibutuhkan sejak usia remaja supaya kesadaran akan masalah ini dapat tertanam sejak usia muda. Kegiatan ekstrakurikuler dalam rangka Adiwiyata, seperti Duta Lingkungan merupakan kegiatan yang dapat menjadi pusat pembelajaran mengenai lingkungan hidup yang baik di sekolah, juga menimbulkan banyak perubahan positif bagi perilaku bermasyarakat.

\section{UCAPAN TERIMA KASIH}

Penghargaan dan ucapan terima kasih penulis sampaikan kepada LRPM Universitas Presiden yang telah mendanai kegiatan pengabdian masyarakat ini. Ucapan terima kasih juga kepada Kepala Sekolah, Guru, dan Duta Lingkungan di SMAN 1 Cikarang Pusat, khususnya kepada Ibu Ir. Dwi Uning Hidayati (Ketua Adiwiyata), dan Ibu Diani Yudiwati, S.Pd. (Sekretaris Adiwiyata), yang berkenan berkolaborasi dan mendukung dalam kegiatan KPM ini. Ucapan terima kasih juga kepada mahasiswa Teknik Lingkungan 2017 (Julio, Asyifa, dan Kevin Mulia), 2018 (Annisa, Anggi, Winda, Fauzan, Steve), dan 2019 (Fathimah) yang telah mengelola kegiatan pengabdian masyarakat ini dengan sangat baik.

\section{REFERENSI}

Alencastro, D. (2012). Pollution due to Plastics and Microplastics in Lake Geneva and in the Mediterranean Sea. Arch. Sci, 65, 157-164. 
Ambari M. (2018). Ancaman Sampah Plastik untuk Ekosistem Laut Harus Segera Dihentikan, Bagaimana Caranya?. Diunduh dari:

https://www.mongabay.co.id/2018/07/26/ancaman-sampah-plastik-untuk-ekosistem-lautharus-segera-dihentikan-bagaimana-caranya/

Browne, M. A., Crump, P., Niven, S. J., Teuten, E., Tonkin, A., Galloway, T., \& Thompson, R. (2011). Accumulation of Microplastic on Shorelines Worldwide: Sources and Sinks. Environmental Science \& Technology, 45(21), 9175-9179.

Ismail, Y., \& Sidjabat, F. M. (2019). Community Empowerment in Household Waste Management. Journal of Community Engagement, 1(01), 24-29.

J. R. Jambeck, R. Geyer, C. Wilcox, T. R. Siegler, M. Perryman, A. Andrady, R. Narayan, K.L. Law. (2015). Plastic Waste Inputs from Land into the Ocean. Science, 347(6223): 768-771.

Kim, J. S., Lee, H. J., Kim, S. K., \& Kim, H. J. (2018). Global Pattern of Microplastics (MPs) in Commercial Food-grade Salts: Sea Salt as an Indicator of Seawater MP Pollution. Environmental Science \& Technology, 52(21), 12819-12828.

Peraturan Presiden RI Nomor 15 Tahun 2018 tentang Percepatan Pengendalian Pencemaran dan Kerusakan Daerah Aliran Sungai Citarum.

Peraturan Presiden RI Nomor 83 Tahun 2018 tentang Penanganan Sampah Laut.

Siaran Pers Greenpeace Indonesia. (2018). Lebih dari 90\% Merek Garam yang Disampel Secara Global Ditemukan Mengandung Mikroplastik. Diunduh dari: https://www.greenpeace.org/indonesia/siaran-pers/1747/lebih-dari-90-merek-garamyang-disampel-secara-global-ditemukan-mengandung-mikroplastik/

Sidjabat, F. M., Ismail, Y., \& Rismauli, E. (2020). Pendidikan Lingkungan: Plastic Pollution Awareness di Desa Jatireja, Cikarang, Jawa Barat. Academics in Action Journal of Community Empowerment, 1(2), 88-100.

Wahyuni, T. (2016). Indonesia Penyumbang Sampah Plastik Terbesar Ke-dua Dunia. Diunduh dari: https://www.cnnindonesia.com/gaya-hidup/20160222182308-277112685/indonesia-penyumbang-sampah-plastik-terbesar-ke-dua-dunia 